\begin{abstract}
Iranica
Abstracta Iranica Revue bibliographique pour le domaine irano-aryen

Volume 32-33 | 2013

Comptes rendus des publications de 2009-2010
\end{abstract}

\title{
Mikhaïl Svanidzé. La France et la guerre entre l'Empire ottoman et la Perse (1548-1555)
}

\section{Giorgio Rota}

\section{(2) OpenEdition \\ 1 Journals}

\author{
Electronic version \\ URL: http://journals.openedition.org/abstractairanica/40688 \\ DOI: 10.4000/abstractairanica.40688 \\ ISSN: 1961-960X \\ Publisher: \\ CNRS (UMR 7528 Mondes iraniens et indiens), Éditions de l'IFRI \\ Printed version \\ Date of publication: 1 December 2013 \\ ISSN: 0240-8910

\section{Electronic reference} \\ Giorgio Rota, « Mikhaill Svanidzé. La France et la guerre entre l'Empire ottoman et la Perse (1548-1555) », \\ Abstracta Iranica [Online], Volume 32-33 | 2013, document 260, Online since 01 July 2016, connection \\ on 26 September 2020. URL : http://journals.openedition.org/abstractairanica/40688 ; DOI : https:// \\ doi.org/10.4000/abstractairanica.40688
}

This text was automatically generated on 26 September 2020.

Tous droits réservés 
Mikhail Svanidzé. La France et la guerre entre l'Empire ottoman et la Perse (1548-1555)

Giorgio Rota 


\section{REFERENCES}

Mikhaïl Svanidzé. « La France et la guerre entre l’Empire ottoman et la Perse

(1548-1555) ", in : Florence Hellot-Bellier et Irène Natchkebia, éds., La Géorgie entre Perse et Europe. Paris, L'Harmattan, 2009, p. 37-47.

1 That there was a close relation between the eastern and the western fronts of the Ottoman Empire and that peace or war in central Europe depended very much on the situation along the Safavid-Ottoman border (and vice-versa) are well-known facts that, however, are not always taken into account by modern scholars. Svanidzé's contribution usefully reminds us of these facts. Suleyman the Magnificent signed a fiveyear truce with the king of Hungary, Ferdinand of Habsburg, in 1547 and then launched a new military campaign against Persia in 1548. After the relatively positive conclusion of the war in 1549 and the expiration of the armistice with Ferdinand, the Ottomans invaded Hungary once again in 1552. This new campaign was followed by Safavid attacks on the Ottoman border in 1553 and a new Ottoman invasion of Persia in 1554 that led to the Treaty of Amasya in 1555. As this contribution shows, Hungarian and French diplomats at the Ottoman court were fully aware of this correlation of events. Their efforts are described for preventing or favoring peace between Suleyman and T ahmāsp I, in particular on the eve of the Treaty of Amasya. French diplomacy prevailed, and a 19th century French historian would write that the Treaty was signed sous l'impulsion de l'ambassadeur français (p. 46). As a consequence, both the Sultan and the Roi très chrétien could continue, together, fighting against the Hapsburgs of Spain and Austria.

\section{AUTHORS}

\section{GIORGIO ROTA}

Institut für Iranistik, Wien 